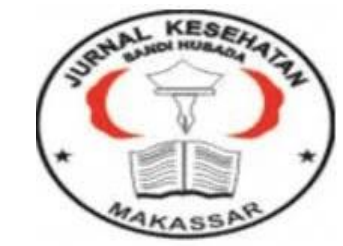

\author{
Jurnal Ilmiah Kesehatan Sandi Husada
}

hhttps://akper-sandikarsa.e-journal.id/JIKSH

Volume 9, Nomor 1, Juni 2020, pp;533-539

p-ISSN: 2354-6093 dan e-ISSN: 2654-4563

DOI: $10.35816 /$ jiskh.v10i2.345

\title{
Madu Sebagai Dressing Pada Penyembuhan Ulkus Diabetikum
}

Honey as Dressing Treatment for Diabetic Ulcer Healing

Cassa Victoria Regia Divandra

Fakultas Kedokteran, Universitas Lampung

\begin{tabular}{l}
\hline \hline \multicolumn{1}{c}{ Artikel info } \\
\hline Artikel history: \\
Received; Mei 2020 \\
Revised: Juni 2020 \\
Accepted; Juni2020
\end{tabular}

\begin{abstract}
Abstrak
Latar Belakang: Diabetes mellitus (DM) merupakan gangguan metabolik berupa meningkatnya kadar gula darah (hiperglikemia) yang diakibatkan oleh gangguan pada produksi insulin, sensitifitas insulin, maupun keduanya. Salah satu komplikasi yang sering terjadi pada pasien dengan DM ialah ulkus diabetikum. Penyembuhan ulkus diabetikum diperlukan dengan tujuan untuk mencegah risiko infeksi dan amputasi. Tatalaksana dressing dalam penyembuhan ulkus diabetikum dapat dilakukan dengan menggunakan pengobatan herbal seperti madu. Tujuan: Mengetahui efektifitas madu sebagai dressing pada penyembuhan ulkus diabetikum. Metode: Menggunakan studi literatur dari jurnal baik nasional maupun internasional dengan cara meringkas topik pembahasan dan membandingkan hasil yang disajikan dalam artikel. Hasil : Madu memiliki sifat anti-bakterial, anti-viral, antifungal, anti-oksidan, dan anti-inflamasi serta berperan menjaga kelembapan pada lokasi luka, dan menjadi batas protektif untuk meminimalisir kontak antara luka dengan agen infeksius. Penggunaan madu sebagai dressing terbukti efektif dan memperpendek masa penyembuhan ulkus diabetikum. Kesimpulan : Penggunaan madu sebagai dressing efektif dalam penyembuhan ulkus diabetikum
\end{abstract}

\begin{abstract}
Background: Diabetes mellitus (DM) is a metabolic disorders characterized by an increase of blood sugar level (hyperglicemia) resulting from defects in insulin secretion, insulin action, or both. The most common complications of patient with DM are diabetic ulcer. Diabetic foot ulcer healing are needs to prevent infection and amputation risk. Dressing treatment in diabetic foot ulcer healing can be done by using traditional treatment such as honey. Objective: To find out more about the efficacy of honey as dressing treatment in diabetic ulcer healing. Methods: Using literature studies from both national and international journals by summarizing the topic of discussion and comparing the results presented in the article. Results: Honey has anti-bacterial, anti-viral, anti-fungal, antioxidant and anti-inflammatory properties and acts to maintain moisture balance at the site of the wound and also has a protective barrier to minimize contact of wound and infectious agents. The use of honey as a dressing treatment has proven to be effective and shorten the healing period of diabetic ulcers. Conclusion: The use of
\end{abstract}


honey is effective as a dressing treatment for diabetic foot ulcer healing.

\section{Keywords:}

Madu;

Ulkus Diabetikum;

Diabetes Mellitus
Corsponden author:

Email: divandracvr@gmail.com

artikel dengan akses terbuka dibawah lisensi BCC BY NC ND-4.0

\section{Pendahuluan}

Diabetes mellitus (DM) merupakan gangguan metabolik berupa meningkatnya kadar gula darah melebihi normal (hiperglikemi) yang diakibatkan oleh gangguan pada produksi insulin, sensitifitas insulin, maupun keduanya (American Diabetes Association, 2014). WHO memperkirakan pada tahun 2014 secara global terdapat 422 juta orang yang berusia lebih dari 18 tahun menderita DM dengan prevalensi terbanyak berasal dari AsiaTenggara (WHO, 2016). Berdasarkan Riskesdas 2013, prevalensi DM di Indonesia meningkat jika dibandingkan dengan tahun 2007 yang sebelumnya sebesar 1,1\% menjadi 2,1\%. Data di atas menunjukkan tingginya prevalensi penderita DM di Indonesia dan diprediksi pada masa mendatang akan terjadi peningkatan jumlah penderita DM (Soelistijo et al., 2015). Komplikasi pada DM terbagi menjadi 2, yakni komplikasi makrovaskular dan mikrovaskular. Salah satu komplikasi mikrovaskular yang sering terjadi ialah neuropati perifer (Marissa \& Ramadhan, 2017). Neuropati perifer diabetik ditandai dengan gejala seperti berkurangnya sensasi nyeri dan suhu, perasaan kesemutan, atau nyeri tajam seperti terbakar dan tertusuk-tusuk (Suyanto, 2017). Neuropati perifer merupakan penyebab terjadinya ulkus diabetikum yang sulit dikontrol. Penurunan sensasi nyeri dapat menyebabkan peningkatan risiko terjadinya kerusakan kulit baik karena trauma maupun adanya tekanan berlebih pada kaki yang kemudian berkembang menjadi lesi dan infeksi (Fitria et al., 2017).

Penyembuhan ulkus diabetikum ditujukan untuk mengurangi risiko infeksi dan amputasi, meningkatkan kualitas hidup dan mengurangi biaya pemeliharaan kesehatan. Perawatan yang dilakukan tergantung pada keparahan ulkus serta ada atau tidaknya iskemia jaringan sekitar (Rosyid, 2017). Hal yang utama pada penyembuhan ulkus diabetikum meliputi kontrol kadar gula darah secara berkala, debridemen, mengurangi tekanan pada bagian tubuh yang mengalami luka, memberikan antibiotik adekuat untuk mengatasi infeksi, dan dressing (penutupan luka) untuk mempertahankan kelembapan pada lesi (Karimi et al., 2019). Tatalaksana dressing dalam penyembuhan ulkus diabetikum dapat dilakukan dengan menggunakan pengobatan herbal seperti madu. Secara umum madu memiliki kandungan seperti glukosa, fruktosa, sukrosa, air dan beberapa senyawa asam amino, vitamin, serta mineral yang berperan dalam proses penyembuhan luka seperti antiinflamasi, anti-bakteri, dan anti-oksidan (Gunawan, 2017). Selain itu, madu juga memiiki efek bakterisidal spektrum luas, mempercepat proliferasi epitelium, dan mengabsorpsi edema di sekitar ulkus (Karimi et al., 2019) 


\section{Metode}

Metode yang digunakan berupa studi literatur dari berbagai jurnal nasional maupun internasional. Metode ini digunakan dengan tujuan untuk meringkas kondisi pemahaman terkini mengenai topik yang dibahas dengan menyajikan materi yang telah diterbitkan sebelumnya serta melaporkan informasi fakta dan analisis baru dari studi literatur yang relevan kemudian membandingkan hasil tersebut dalam artikel.

\section{Hasil Dan Pembahasan}

Ulkus diabetikum didefinisikan sebagai lesi pada seluruh lapisan kulit, nekrosis, atau gangren yang dapat terjadi pada seluruh bagian tubuh terutama bagian distal kaki, sebagai akibat dari neuropati perifer pada penderita DM (Rosyid, 2017). Faktor yang berperan dalam terjadinya ulkus diabetikum diantaranya adalah lama mengidap DM, perawatan kaki, trauma, dan adanya neuropati perifer diabetik dan Peripheral Artery Disease (PAD) (Roza et al., 2015). Berdasarkan penelitian, lama DM $\geq 10$ tahun meningkatkan risiko terjadinya ulkus diabetikum akibat dari hiperglikemia kronik yang menyebabkan komplikasi neuropati perifer (Nurhanifah, 2017). Patofisiologi neuropati perifer diabetik bersifat multifaktorial dan diperkirakan merupakan akibat dari gangguan vaskular yang menyebabkan oklusi vasa nervorum; disfungsi endotel; defisiensi sintesis mielin oleh myoinositol dan penurunan aktivitas sodium-potassium adenine triphosphtase (Na-K ATPase); hiperosmolaritas kronis yang menyebabkan edema batang saraf; dan efek peningkatan sorbitol dan fruktosa (Tomic-Canic \& Brem, 2004). Pada penderita DM dengan neuropati, sering terjadi neuropati sensorik dimana adanya kehilangan sensasi terutama pada bagian distal kaki sehingga meningkatkan risiko trauma karena pasien tidak menyadari adanya luka atau tekanan pada kaki yang kemudian dapat menyebabkan lesi dan infeksi (Ningsih et al., 2019). Aliran darah yang tidak lancar dan oksigenasi yang kurang pada PAD dapat menyebabkan luka pada pasien DM sukar sembuh dan kemungkinan infeksi bakteri semakin besar (Roza et al., 2015).

Derajat ulkus diabetikum berdasarkan klasifikasi Wagner ditentukan sesuai dengan luas dan kedalaman luka. Ulkus diabetikum derajat I menunjukkan ulkus superfisial dan terlokalisasi terbatas hanya pada kulit. Ulkus diabetikum derajat II yaitu terdapat ulkus dalam dan disertai selulitis tanpa abses atau kelainan pada tulang. Pada ulkus diabetikum derajat III yaitu ulkus dalam dan disertai dengan kelainan kulit dan abses luas yang dalam. Ulkus diabetikum derajat IV yaitu terdapat gangren terbatas, hanya pada ibu jari kaki atau tumit. Ulkus diabetikum derajat $\mathrm{V}$ menunjukkan adanya gangren yang meluas ke seluruh kaki (Ningsih et al., 2019). Prinsip pada penyembuhan ulkus diabetikum meliputi debridemen, pengurangan tekanan pada lokasi lesi, manajemen infeksi, dan terapi dengan menggunakan dressing untuk menjaga kelembapan lesi (Rosyid, 2017). Dressing merupakan metode perawatan luka dengan prinsip moisture balance menggunakan bahan secara topikal pada lokasi lesi. Metode ini bertujuan untuk memfasilitasi lingkungan lesi menjadi lembap sehingga mempercepat respon inflamasi dan proliferasi sel. Suasana lembap pada lokasi lesi dapat mencegah terjadinya dehidrasi jaringan, kematian sel serta mempercepat angiogenesis (Nabila, 2018). Terdapat beberapa jenis dressing berdasarkan bahan penyusunnya seperti film, composite, hydrogel, hydroccolloid, alginate, foam, dan bahan absorptif lain seperti Negative Pressure Wound Therapy (NPWT) (Rosyid, 2017).

Madu adalah cairan dengan konsistensi kental berasal dari nektar bunga yang diambil dan dimodifikasi oleh lebah madu (Apis mellifera) (Gunawan, 2017). Kandungan yang terdapat 
dalam madu diantaranya ialah karbohidrat, protein, asam amino, vitamin dan mineral. Vitamin yang terdapat dalam madu meliputi Vit. B1, B2, B3, B6, C, A, E, flavonoid, sedangkan untuk kandungan mineralnya meliputi $\mathrm{Na}, \mathrm{Ca}, \mathrm{K}, \mathrm{Mg}, \mathrm{Cl}, \mathrm{Fe}, \mathrm{Zn}$, dan lain lain (Inayah et al., 2012). Beberapa penelitian telah dilakukan untuk melihat manfaat madu terhadap kesehatan, terutama dalam penyembuhan luka. Madu memiliki sifat seperti antibakterial, anti-viral, anti-fungal, anti-oksidan, dan anti-inflamasi (Yaghoobi et al., 2013). Mekanisme madu sebagai anti-bakterial dapat menghambat pertumbuhan bakteri dengan dipengaruhi oleh konsentrasi gula yang tinggi, $\mathrm{pH}$ rendah, hidrogen peroksida, dan beberapa komponen protein. Madu juga memiliki aktivitas anti-virus sebagai efek dari asam lemak 10-HAD (10-Hydroxy-2-Decenoic Acid) yang menstimulasi sel darah putih yang kemudian menyebabkan adhesi sel darah putih terhadap virus. Selain itu, madu juga bekerja sebagai anti-fungal kuat dengan kandungan ekstrak ethanol pada madu (Khan et al., 2018). Sebagai anti-oksidan, madu memiliki kandungan asam fenolik (seperti ellagic, caffeic, p-coumaric dan ferulic acid), flavonoid (seperti apigenin, pinocembrin, kaempferol, quercetin, chrysin dan hesperetin), asam askorbat, dan tokoferol yang dapat mencegah berbagai kondisi klinis seperti inflamasi, gangguan pada arteri koroner, penuaan, dan kanker (Vallianou, 2014).

Dalam penyembuhan luka, madu memiliki peran sebagai agen anti-bakterial, menjaga kelembapan pada lokasi luka, dan menjadi batas protektif untuk meminimalisir kontak antara luka dengan agen infeksius (Meo et al., 2017). Madu dinilai efektif dalam penyembuhan luka dan proses perbaikan jaringan dengan sedikit bahkan tanpa pembentukan jaringan parut (Martinotti \& Ranzato, 2018). Madu juga menginduksi peningkatan kapasitas regeneratif sel-sel kulit serta meningkatkan reepitelisasi yang melibatkan migrasi sel atau dikenal sebagai epithelial-mesenchymal transition (EMT). Pemberian madu secara topikal pada luka menyebabkan keratinosit mengalami perubahan dalam ekspresi gen pengatur EMT. Dalam proses penutupan luka yang melibatkan peran matriks ekstraseluler, setelah pemberian madu keratinosit akan meningkatkan produksi matrix metalloprotease (MMPs) seperti MMP-9 dan kemudian akan mempengaruhi degradasi kolagen tipe IV (Martinotti \& Ranzato, 2018). Beberapa penelitian telah dilakukan untuk mengetahui efektifitas dressing madu baik dalam penyembuhan ulkus diabetikum maupun perbandingannya dengan dressing menggunakan bahan lain. Berdasarkan penelitian oleh yang dilakukan oleh Nabhani \& Widiyastuti (2017), tentang pengaruh madu terhadap penyembuhan luka gangren pada pasien DM dengan jumlah responden sebanyak 20 orang yang melakukan kunjungan ke Poliklinik Omah Luka, didapatkan hasil analisis bivariat $t$ hitung 5.000 dan $p$ value 0,015 karena hasil thitung diatas harga atau $>$ table t: 2,35 dan $\mathrm{p}<0,05$. Dari hasil diatas dapat disimpulkan bahwa madu memiliki efektifitas dalam penyembuhan luka gangren pada pasien DM. Hal ini juga sejalan dengan studi kasus penggunaan dressing madu pada penderita ulkus diabetikum oleh Suriadi et al. (2018) pada 4 responden yang menyatakan bahwa madu memiliki efektifitas dalam penyembuhan ulkus diabetikum dengan rata-rata waktu penyembuhan yang lebih cepat.

Berdasarkan dua penelitian dalam tinjauan pustaka sistematis oleh Insani et al., (2017) dressing menggunakan madu memiliki efek untuk mengurangi edema di sekitar ulkus dan mengurangi discharge pada luka. Selain itu, dalam penelitian tersebut juga dilaporkan rata rata masa penyembuhan ulkus diabetikum dengan menggunakan dressing madu relatif lebih cepat jika dibandingkan dengan dressing menggunakan povidone iodine. Hal ini sejalan dengan penelitian pada tinjauan pustaka naratif dan meta analisis oleh Oryan et al., (2016), yang menyatakan bahwa rata-rata waktu penyembuhan ulkus diabetikum 
menggunakan dressing madu lebih cepat dibandingkan kontrol $(P>0,005)$. Hal ini juga didukung 6 dari 7 penelitian dalam tinjauan pustaka literatur oleh Pratama \& Rochmawati (2019) juga menyatakan bahwa madu dapat menyembuhkan ulkus diabetikum dan memperpendek masa penyembuhan. Sedangkan 1 penelitian lainnya pada tinjauan pustaka literatur tersebut menyatakan efektifitas nAg lebih baik dibandingkan dengan madu.

Berdasarkan penelitian untuk membandingkan efektifitas dressing madu dan sofratulle pada ulkus diabetikum yang dilakukan oleh Awaluddin et al. (2019) terhadap 20 responden, didapatkan hasil rata-rata skor penilaian status luka diabetik sebelum dan sesudah perawatan menggunakan madu adalah 24,60 dan 32,40 dengan hasil uji statistik ( $\mathrm{p}$ value $=0,000<\alpha$ ) sedangkan hasil rata-rata skor penilaian status luka diabetik sebelum dan sesudah perawatan menggunakan sofratulle adalah 25,50 dan 29,30 dengan hasil uji statistik ( $p$ value $=0,006<\alpha$ ). Dari hasil diatas dapat disimpulkan bahwa madu memiliki efektifitas yang lebih tinggi dibandingkan dengan sofratulle. Data lain juga didapatkan berdasarkan penelitian uji acak terkendali yang dilakukan oleh Karimi et al. (2019) untuk menilai perbandingan efektifitas madu dan minyak zaitun sebagai dressing dalam penyembuhan ulkus diabetikum, dan didapatkan hasil bahwa efektifitas madu sama dengan efektifitas minyak zaitun dalam penyembuhan ulkus diabetikum

\section{Simpulan Dan Saran}

Madu dengan kandungan karbohidrat, protein, asam amino, vitamin dan mineral yang terdapat didalamnya merupakan alternatif pengobatan ulkus diabetikum sebagai tatalaksana dressing yang efektif dengan sifat anti-bakterial, anti-viral, anti-fungal, antioksidan, dan anti-inflamasi untuk mempercepat masa penyembuhan. Masih diperlukan penelitian lebih lanjut untuk mengetahui jenis madu yang digunakan dan potensinya dalam penyembuhan ulkus diabetikum.

\section{Daftar Rujukan}

American Diabetes Association. (2014). Diagnosis and classification of diabetes mellitus. Diabetes Care, 37(SUPPL.1), 81-90. https://doi.org/10.2337/dc14-S081

Awaluddin, Syarifah, A., \& Nurhayatina. (2019). Perbedaan Efektifitas Madu Dan Sofratulle Terhadap Penyembuhan Luka Diabetik Pada Pasien Diabetes Mellitus. Ensiklopedia of Journal, 2(1), 187-195.

Fitria, E., Nur, A., Marissa, N., \& Ramadhan, N. (2017). Karakteristik Ulkus Diabetikum pada Penderita Diabetes Mellitus di RSUD dr. Zainal Abidin dan RSUD Meuraxa Banda Aceh. Buletin Penelitian Kesehatan, 45(3), 153-160. https://doi.org/10.22435/bpk.v45i3.6818.153-160

Gunawan, N. A. (2017). Madu : Efektivitasnya untuk Perawatan Luka. Continuing Profesional Development-249, 44(2), 138-142.

Inayah, Marianti, A., \& Lisdiana. (2012). Unnes Journal of Life Science Efek Madu Randu dan Kelengkeng dalam Menurunkan Kolesterol pada Tikus Putih Hiperkolesterolemik Inayah , Aditya Marianti , Lisdiana Info Artikel Abstrak Abstra ct. 1(1), 5. 
Insani, I. B., Widayanti, N., \& Rifki, A. (2017). Honey As A Treatment For Diabetic Foot Ulcer: A Systematic Review. Jurnal Plastik Rekonstruksi, 3(2), 45-51. https://doi.org/10.14228/jpr.v3i2.201

Karimi, Z., Behnammoghadam, M., Rafiei, H., Abdi, N., Zoladl, M., Talebianpoor, M. S., Arya, A., \& Khastavaneh, M. (2019). Impact of olive oil and honey on healing of diabetic foot: A randomized controlled trial. Clinical, Cosmetic and Investigational Dermatology, 12, 347-354. https://doi.org/10.2147/CCID.S198577

KEMENKES RI. (2013). Pokok-Pokok hasil Riskesdas Indonesia 2013. Badan Penelitian Dan Pengembangan Kesehatan, iii. https://doi.org/10.1017/CB09781107415324.004

Khan, S. U., Anjum, S. I., Rahman, K., Ansari, M. J., Khan, W. U., Kamal, S., Khattak, B., Muhammad, A., \& Khan, H. U. (2018). Honey: Single food stuff comprises many drugs. Saudi Journal of Biological Sciences, 25(2), 320-325. https://doi.org/10.1016/j.sjbs.2017.08.004

Marissa, N., \& Ramadhan, N. (2017). Kejadian ulkus berulang pada pasien diabetes mellitus. Sel Jurnal Penelitian Kesehatan, 4(2), 91-99. https://doi.org/10.22435/sel.v4i2.1471

Martinotti, S., \& Ranzato, E. (2018). Honey, wound repair and regenerative medicine. Journal of Functional Biomaterials, 9(2). https://doi.org/10.3390/jfb9020034

Meo, S. A., Al-Asiri, S. A., Mahesar, A. L., \& Ansari, M. J. (2017). Role of honey in modern medicine. Saudi Journal of Biological Sciences, 24(5), 975-978. https://doi.org/10.1016/j.sjbs.2016.12.010

Nabhani, N., \& Widiyastuti, Y. (2017). Pengaruh Madu Terhadap Proses Penyembuhan Luka Gangren Pada Pasien Diabetes Mellitus. Profesi (Profesional Islam) : Media Publikasi Penelitian, 15(1), 69. https://doi.org/10.26576/profesi.241

Nabila, N. P. (2018). Proses Penyembuhan Luka Ulkus Diabetikum Dengan Metode Modern Dressing Diklinik Maitis Efrans Wound Care. Jurnal Media Kesehatan, 10(2), 146151. https://doi.org/10.33088/imk.v10i2.336

Ningsih, A., Darwis, I., Graharti, R., Kedokteran, F., \& Lampung, U. (2019). Terapi Madu Pada Penderita Ulkus Diabetikum Honey Therapy In Diabetic Ulcus Patients. Medula, 9(12), 192-197.

Nurhanifah, D. (2017). Faktor-Faktor Yang Berhubungan Dengan Ulkus Kaki Diabetik Di Poliklinik Kaki Diabetik. Healthy-Mu Journal, 1(1), 32. https://doi.org/10.35747/hmj.v1i1.67

Oryan, A., Alemzadeh, E., \& Moshiri, A. (2016). Biological properties and therapeutic activities of honey in wound healing: A narrative review and meta-analysis. Journal of Tissue Viability, 25(2), 98-118. https://doi.org/10.1016/j.jtv.2015.12.002

Pratama, E. F., \& Rochmawati, E. (2019). Dressing Madu Pada Perawatan Diabetic Foot Ulcers. Jambura Nursing Journal, 1(2), 56-64. https://doi.org/10.37311/jnj.v1i2.2475

Rosyid, F. N. (2017). Etiology, pathophysiology, diagnosis and management of diabetics' foot ulcer. International Journal of Research in Medical Sciences, 5(10), 4206. https://doi.org/10.18203/2320-6012.ijrms20174548

Roza, R. L., Afriant, R., \& Edward, Z. (2015). Faktor Risiko Terjadinya Ulkus Diabetikum pada Pasien Diabetes Mellitus yang Dirawat Jalan dan Inap di RSUP Dr. M. Djamil dan RSI Ibnu Sina Padang. Jurnal Kesehatan Andalas, 4(1), 243-248. https://doi.org/10.25077/jka.v4i1.229

Soelistijo, S., Novida, H., Rudijanto, A., Soewondo, P., Suastika, K., Manaf, A., Sanusi, H., Lindarto, D., Shahab, A., Pramono, B., Langi, Y., Purnamasari, D., \& Soetedjo, N. 
(2015). Konsesus Pengelolaan Dan Pencegahan Diabetes Melitus Tipe2 Di Indonesia 2015. In Perkeni.

Suriadi, Rhamdaniyati, Sudirjo, W., Ali, S., Nurpiyanti, A., Kardiatun, T., \& Jiu, C. K. (2018). Case report on the use of a honey on diabetic foot ulcer patients. International Journal of Indonesian National Nurses Association (IJINNA), 1(1), 98-104. https://doi.org/10.32944/ijinna.v1i1.23

Suyanto. (2017). Gambaran Karakteristik Penderita Neuropati Perifer Diabetik. Nurscope, Jurnal Keperawatan Dan Pemikiran Ilmiah, 3(1), 1-6.

Tomic-Canic, M., \& Brem, H. (2004). Gene array technology and pathogenesis of chronic wounds. American Journal of Surgery, 188(1 SUPPL. 1), 67-72. https://doi.org/10.1016/S0002-9610(03)00293-9

Vallianou, N. G. (2014). Honey and its Anti-Inflammatory, Anti-Bacterial and Anti-Oxidant Properties. General Medicine: Open Access, 02(02). https://doi.org/10.4172/2327-5146.1000132

WHO. (2016). Global Report on Diabetes. Isbn, 978, 6-86. http://www.who.int/about/licensing/copyright form/index.html\%0Ahttp://ww w.who.int/about/licensing/copyright form/index.html\%0Ahttps://apps.who.int/i ris/handle/10665/204871\%0Ahttp://www.who.int/about/licensing/

Yaghoobi, R., Kazerouni, A., \& kazerouni, O. (2013). Evidence for clinical use of honey in wound healing as an anti-bacterial, anti-inflammatory anti-oxidant and anti-viral agent: A review. Jundishapur Journal of Natural Pharmaceutical Products, 8(3), 100-104. https://doi.org/10.17795/jjnpp-9487 